\title{
イネ中苗育苗におけるタチガレン剤の施用方法に関する検討
}

\author{
（2）出芽時の低温によるイネ苗立枯病の発生と \\ タチガレン粉剂・液剂処理の効果 \\ 加藤重博 - 中西逸朗 - 高日幸義 - 中神和人 - 小川正已 -太田 吴 - 田中治一 \\ (三共農薬研究所)
}

育苗温度とイネ苗立枯病の発生との関係については, 苗代育苗, 稚苗箱育苗において多くの研究がなされ， 育苗時の低温により，ピシウム菌，フザリウム菌に起 因する苗立枯病が多発すると報告されている1,2)、箻 者らは, 中堺育苗におけるタチガレン剂の施用方法に 関する試験の一環として, 出芽時に低温に遭遇した時 の苗立枯病の発生とタチガレン粉剂・液剂処理の効果 とを検討した。

\section{(I) 試験方法}

1）試験 $\mathrm{A}$ : 本試験は 1 月 23 日〜 2 月 27 日にガラス 温室内で行なった。 4 種類の土壤（三上土壤·水田土，

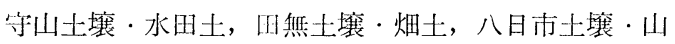
土）を供試し，「日本晴」種子をベンレート $\mathrm{T}$ 水和剂 で消毒した後, 箱当り $120 \mathrm{~g}$ 播種した。播種後 2 週間 は低温にあわせるために，ガラス温室の加温をやめて 育苗し, それ以後は加温して育苗した。

2）試験 B：本試験は 1 月 23 日〜 3 月 9 日にビニー ルハウス内のビニールトンネルで行なった． 2 種類の 土壤 (三上土壤, 守山土畩) を供試し, 播種までは試 験 $\mathrm{A}$ と同様にした。播種後は育苗終期までビニール八 ウス内のビニールトンネルで, 被覆資材による昇温を 図るだけで充苗した。

\section{（II）試験結果および考察}

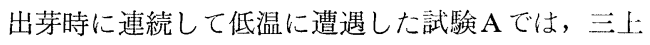
土壤, 守山土壤, 田無土壤の無処理区で, ピシウム菌, フザリウム菌に起因する苗立枯病がスボット状に多発 した (スポット状苗立枯病). タチガレン粉剤を箱当
り $8 \mathrm{~g}$ あるいは $12 \mathrm{~g}$ 混和した区では，スボット状苗立 枮病は全く発生せず, タチガレン粉剤混和の効果は顕 著であった。さらに, タチガレン粉剤 $8 \mathrm{~g} /$ 箱混和にタ テガレン液剤の 500 倍液を 1 回あるいは 2 回追加灌注 した区では，移植時の健苗率も高く，効果は非常に安 定していた。八日市土裹では，無処理区においても苗 立枯病は少発生であったが，タチガレン剤処理区では 全般的に健苗率が高かった。

出芽時から育苗終期まで低温に推移した試験 Bでは, 三上土壤, 守山上壤の無処理区で試験 $\mathrm{A}$ と同様にスボ ット状苗立枯病が発生した. タチガレン粉剂を箱当り $8 \mathrm{~g}$ あるいは $12 \mathrm{~g}$ 混和した区では，スボット状苗立枮 病の発生は2られず効果は極めて高かった。さらに, タチガレン粉剤 $8 \mathrm{~g} /$ 箱混和にタチガレン液剤の 500 倍 液を 1 回あるいは 2 回追加灌注した区では, 効果が一 層安定した (第 1 表).

中苗育苗では, 播種直後から被覆資材により昇温を 图るだけで亩苗するので，出芽時に低温に遭遇して苗 立枯病が多発する場合も多いが, タチガレン粉剤混和 とタチガレン液剤追加灌注とを組み合せた施用体系で 苗立枯病の発生をよく防除できると考える。

\section{引用 文 献}

1）千葉末作 - 千葉順逸 - 島田慶也. (1972) 北日本 病虫研報 $23: 151$

2）及川俊雄. 大友義視. (1976) 北日本病虫研報 $27: 58$

第 1 表 育苗期の低温によるイネ苗立枯病の発生とタチガレン粉剤・液剤処理の効果（三上土壤）

\begin{tabular}{clccc}
\hline $\begin{array}{c}\text { タチガレン粉剤 } \\
\mathrm{g} / \text { 箱 }\end{array}$ & $\begin{array}{c}\text { タチガレン液剤 } \\
500 \text { 倍, }\end{array}$ & $\begin{array}{c}\text { 草 } \\
\text { 丈 }(\mathrm{mm}) \\
45 \text { 箱 }\end{array}$ & $\begin{array}{c}\text { スポット状苗立枯病 } \\
\text { の発生面積 }\end{array}$ & $\begin{array}{c}\text { 健 苗率 }(\%) \\
45 \text { 日目 }\end{array}$ \\
\hline 0 & 無灌注 & 122.2 & ++++ & 51.7 \\
4 & 同 上 & 127.3 & \pm & 86.3 \\
8 & 同 上 & 123.3 & - & 92.1 \\
12 & 同 上 & 135.7 & - & 95.5 \\
8 & 7 日目灌注 & 124.9 & - & 97.6 \\
8 & $7 \cdot 14$ 日目灌注 & 129.9 & - & 98.3 \\
\hline
\end{tabular}

スポット状苗立枯病の発生面積 : - $0 \%, \quad$ 土 $<5 \%,++++30 \sim 40 \%$ 